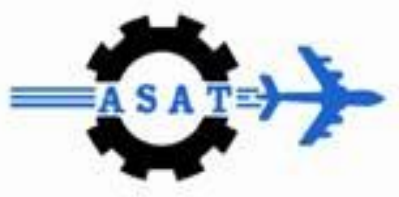

\title{
Ballistic Range Potential of Scaled Gun Barrels Firing Saboted Dart-Like Barrage Round
}

\author{
Hatem H. Daken ${ }^{*}$
}

\begin{abstract}
Providing the marines expeditionary and amphibious assault forces with long range surface fire support missions is one of the responsibilities of the U.S. Navy. Meeting the U.S. Marine Corps (USMC) Ship-To-Objective Maneuver (STOM) and Operational Maneuver From The Sea (OMFTS) requirements required the prediction of the maximum achievable ballistic ranges for a $100 \mathrm{lbs}, 5^{\prime \prime}$ diameter/12 calibers, GPS guided, dart-like barrage round when fired from 5", 155mm, 8", 10", 12", 14", 16", and 18" bore barrels that are 64 and 200 calibers in length at maximum breech pressures of $448 \mathrm{MPa}(65 \mathrm{Ksi})$ and $896 \mathrm{MPa}$ (130Ksi.)
\end{abstract}

Keywords: SIMULINK, CONPRES, Interior Ballistics, Exterior Ballistics, Surface Fire Support

\section{Nomenclature}

\begin{tabular}{|c|c|}
\hline A & Projectile Base Area, $\mathrm{m}^{2}$ \\
\hline $\mathrm{BE}$ & Ballistic Efficiency, Equation 12 \\
\hline d & Bore diameter, meter \\
\hline $\mathrm{E}_{\mathrm{i}}$ & Gas Internal Energy, MJ, Equation 7 \\
\hline $\mathrm{E}_{\mathrm{p}}$ & Propellant Energy, MJ, Equation 6 \\
\hline ER & Expansion Ratio, Equation 11 \\
\hline I & Propellant Impetus, Joule/kg \\
\hline $\mathrm{K}_{\mathrm{g}}$ & Gas Kinetic Energy, MJ, Equation 5 \\
\hline $\mathrm{K}_{\mathrm{p}}$ & Projectile Kinetic Energy, MJ, Equation 4 \\
\hline $\mathrm{m}_{\mathrm{c}}$ & Charge Mass, kg \\
\hline $\mathrm{m}_{\mathrm{p}}$ & Projectile mass, $\mathrm{kg}$ \\
\hline $\mathrm{P}_{\mathrm{c}}$ & Constant Breech Pressure, MPa \\
\hline$\overline{\mathrm{P}}$ & Space Mean Pressure, MPa, Equation 8 \\
\hline $\mathrm{P}_{\mathrm{b}}$ & Base Pressure at Muzzle Exit, MPa, Equation 9 \\
\hline $\mathrm{PE}$ & Piezometric Efficiency, Equation 13 \\
\hline $\mathrm{V}_{\mathrm{bf}}$ & Chamber Volume at Propellant Burn-out, $\mathrm{m}^{3}$, Equation 3 \\
\hline $\mathrm{V}_{\mathrm{c}}$ & Chamber Volume, $\mathrm{m}^{3}$ \\
\hline $\mathrm{V}_{\mathrm{cf}}$ & Free Chamber Volume accounting for Propellant Covolume, $\mathrm{m}^{3}$, Equation 1 \\
\hline $\mathrm{V}_{\mathrm{mf}}$ & $\begin{array}{l}\text { Free Gun Volume at Projectile Muzzle Exit, adjusting for Propellant } \\
\text { Covolume, } \mathrm{m}^{3} \text {, Equation } 2\end{array}$ \\
\hline $\mathrm{U}_{\mathrm{m}}$ & Projectile Muzzle Exit Velocity, m/sec \\
\hline
\end{tabular}

\footnotetext{
"Ph.D., Senior Structural Analysis Scientist/Engineer, Boeing Commercial Airplanes, The Boeing Company, Seattle, WA, USA (work was performed while working as the Principal Engineer, Defense Technology Inc., DTI, Arlington, VA, USA), hatemdaken@aol.com
} 


$\begin{array}{ll}\mathrm{x}_{\mathrm{b}} & \text { Projectile Travel at Propellant Burn-out, meter } \\ \mathrm{x}_{\mathrm{t}} & \text { Projectile Travel at Muzzle Exit, meter, Equation } 10 \\ \gamma & \text { Ratio of Specific Heats } \\ \eta & \text { Propellant Covolume, } \mathrm{m}^{3} / \mathrm{kg}\end{array}$

\section{Introduction}

The U.S. Navy's Naval Surface Fire Support Systems (NSFS) Program Office PMS 529, which is currently reorganized into the Program Executive Office (PEO) for Integrated Warfare Systems (IWS) Code PEO IWS 3C, has developed visionary objectives for using shipboard gun systems to provide marines expeditionary and amphibious assault forces with long range surface fire support missions that entail suppression of enemy defenses and artillery, execution of quick response call fires, and interdiction of moving counter offensives in addition to executing traditional destruction fires, preparation fires, counter fires, suppression fires, and area neutralization fires. Validation of these objectives and meeting the USMC STOM/OMFTS requirements ${ }^{1,2}$, Figure 1 , demanded modeling and simulating the range potential of a $100 \mathrm{lbs}, 5$ " diameter/12 calibers, GPS guided, dart-like barrage round, Figures 2 and 3, when fired from two sets of different caliber guns with barrel lengths of either 64 or 200 calibers, Figure 4, that operate at a maximum breech pressure of $448 \mathrm{MPa}(65 \mathrm{Ksi})$. A future projection of this range potential was also performed when gun technology permitting a maximum breech pressure of $896 \mathrm{MPa}(130 \mathrm{Ksi})$ becomes available.

\section{Analysis Methodology}

The analysis consisted of the following interior and exterior ballistics tasks and subtasks:

\section{Interior Ballistics}

Shipboard Gun and Round Constraints

Establishing values for the following system parameters: (1) maximum breech pressure; (2) maximum round $\mathrm{G}$ loading; (3) maximum muzzle exit pressure; (4) propellant composition; and (5) travel at burnout. The table below shows the parameters chosen.

Table 1: Gun, Projectile, and Propellant Constraints

\begin{tabular}{l|l|l}
\hline \hline \multicolumn{1}{c|}{ Parameter } & \multicolumn{1}{|c}{ Value } & \multicolumn{1}{c}{ Rationale } \\
\hline \multirow{2}{*}{ Maximum Breech Pressure } & $\begin{array}{l}65 \mathrm{Ksi}, \\
130 \mathrm{Ksi}\end{array}$ & Customer specified \\
\hline Maximum G Loading & $12.5 \mathrm{KGs}$ & Customer Specified \\
\hline Max. Muzzle Exit Pressure & Open & Relaxed by Customer \\
\hline Propellant Composition & EX99 & Same as 5" /62 firing ERGM \\
\hline Travel at Burnout & $\begin{array}{l}<64 \text { Calibers } \\
<200 \text { Calibers }\end{array}$ & Efficient use of propellant \\
\hline \hline
\end{tabular}

\section{Gun System Characteristics}

The CONPRESS interior ballistics model, illustrated in Figure 5, is used to compute the maximum muzzle velocity that satisfies the above constraints for each caliber. Additional characteristics needed are: (1) G loading; (2) charge mass, (3) chamber volume; (4) muzzle exit pressure; and (5) travel at propellant burnout. 
CONPRESS $^{3,4}$ is a constant pressure interior ballistics code that predicts the performance of a gun from its physical parameters, the masses of the propelling charge and projectile, and the thermochemical properties of the propellant. The CONPRESS code is a FORTRAN based computer program. It is described in References [3] and [4]. This code was adapted to Microsoft Excel. A snapshot of this model is shown in Figure 6. Excel's Solver was used to find the maximum muzzle exit velocity, $\mathrm{U}_{\mathrm{m}}$, by changing the charge weight, $\mathrm{m}_{\mathrm{c}}$, and chamber volume, $V_{c}$, while ensuring that: (1) the $G$ loading is less than or equal to 12500; (2) the travel at propellant burn-out is less than or equal to the barrel length; and (3) the validation tests for $\mathrm{m}_{\mathrm{c}}$ and $\mathrm{x}_{\mathrm{b}}$ are passed.

CONPRESS uses the following assumptions to calculate the energy imparted into the projectile by the gun:

$\circ \quad$ The Lagrange gradient adequately describes the gas pressure and velocities in the gun.

- The propellant burns in an ideal manner. (This means, it is instantaneously converted into gas.)

- The burn rate of the propellant is controlled to provide a constant chamber pressure until burnout.

- After burnout, the gas expands adiabatically.

- The gas is polytropic.

- The Nobel-Able equation of state is valid.

- No energy loss occurs during the ballistic cycle.

$\circ$ The projectile base area equals the cross-sectional area of the tube.

CONPRESS uses the following equations to compute its parameters. The conventions are explained in the nomenclature section:

$\mathrm{V}_{\mathrm{cf}}=\mathrm{V}_{\mathrm{c}}-\eta \cdot \mathrm{m}_{\mathrm{c}}$

$\mathrm{V}_{\mathrm{mf}}=\mathrm{V}_{\mathrm{c}}+\mathrm{A} \cdot \mathrm{x}_{\mathrm{t}}-\eta \cdot \mathrm{m}_{\mathrm{c}}$

$\mathrm{V}_{\mathrm{bf}}=\frac{\mathrm{m}_{\mathrm{c}} \cdot \mathrm{I} \cdot\left(1+\frac{\mathrm{m}_{\mathrm{c}}}{2 \cdot \mathrm{m}_{\mathrm{p}}}\right)}{\gamma \cdot\left(1+\frac{\mathrm{m}_{\mathrm{c}}}{3 \cdot \mathrm{m}_{\mathrm{p}}}\right)}+\frac{\gamma-1}{\gamma} \cdot \mathrm{V}_{\mathrm{cf}}$

$\mathrm{K}_{\mathrm{p}}=\frac{\mathrm{P}_{\mathrm{c}}}{\left(1+\frac{\mathrm{m}_{\mathrm{c}}}{2 \cdot \mathrm{m}_{\mathrm{p}}}\right)} \cdot\left[\frac{\gamma}{\gamma-1} \cdot \mathrm{V}_{\mathrm{bf}}-\mathrm{V}_{\mathrm{cf}}-\frac{\mathrm{V}_{\mathrm{mf}}}{\gamma-1} \cdot\left(\frac{\mathrm{V}_{\mathrm{bf}}}{\mathrm{V}_{\mathrm{mf}}}\right)^{\gamma}\right]$

$\mathrm{K}_{\mathrm{g}}=\frac{\mathrm{m}_{\mathrm{c}}}{3 \cdot \mathrm{m}_{\mathrm{p}}} \cdot \mathrm{K}_{\mathrm{p}}$ 


$$
\begin{aligned}
& \mathrm{E}_{\mathrm{p}}=\frac{\mathrm{m}_{\mathrm{c}} \cdot \mathrm{I}}{\gamma-1} \\
& \mathrm{E}_{\mathrm{i}}=\mathrm{E}_{\mathrm{p}}-\mathrm{K}_{\mathrm{g}}-\mathrm{K}_{\mathrm{p}} \\
& \overline{\mathrm{P}}=\frac{\mathrm{E}_{\mathrm{i}}}{\mathrm{V}_{\mathrm{mf}}} \cdot(\gamma-1) \\
& \mathrm{P}_{\mathrm{b}}=\frac{\overline{\mathrm{P}}}{1+\frac{\mathrm{m}_{\mathrm{c}}}{3 \cdot \mathrm{m}_{\mathrm{p}}}} \\
& \mathrm{x}_{\mathrm{b}}=\frac{\mathrm{V}_{\mathrm{bf}}+\eta \cdot \mathrm{m}_{\mathrm{c}}-\mathrm{V}_{\mathrm{c}}}{\mathrm{A}} \\
& \mathrm{ER}=\frac{\mathrm{V}_{\mathrm{c}}+\mathrm{A} \cdot \mathrm{x}_{\mathrm{t}}}{\mathrm{V}_{\mathrm{c}}} \\
& \mathrm{BE}=\frac{\mathrm{K}_{\mathrm{p}}}{\mathrm{E}_{\mathrm{i}}} \\
& \mathrm{P}_{\mathrm{c}} \cdot \mathrm{A} \cdot \mathrm{x}_{\mathrm{t}}
\end{aligned}
$$

Once the maximum muzzle exit velocity is computed for each gun caliber, barrel length, and breech pressure, an exterior ballistics model using the lumped mass approach was developed.

\section{Exterior Ballistics}

This model was used to compute the maximum achievable range and optimum launch angle for each gun caliber, barrel length, and breech pressure set. The model entails the following modules;

\section{Drag Function}

This function was used to compute the total aerodynamic drag coefficient of the barrage round as a function of its flight Mach number and geometric characteristics using the $\mathrm{McDrag}^{5}$ model. The core of this model is illustrated in Figure 7.

\section{The Atmosphere}

This module uses the U.S. Standard Atmosphere ${ }^{6}$ database to calculate the air temperature, pressure, air density, and speed of sound for various geopotential flight altitudes. The database was extended for use at altitudes over $85 \mathrm{~km}$. 


\section{Analysis Limitations}

\section{Sabot Design}

The design of different caliber sabots, its volume, and weight calculations have the following limitations:

- Designs were mainly intended to provide ballpark weight estimates of different caliber sabots and were not intended to be in-depth detailed minimum weight designs.

- The lower specific weights of advanced and innovative materials (ceramics, composites, and thermoplastics) were not addressed since cost minimization was a main consideration.

\section{CONPRESS - Constant Breech Pressure Interior Ballistics Model}

- Assumes a barrel with no well-defined chamber or transition region.

- Provides an absolute measure of maximum muzzle velocity performance.

\section{McDrag Function and Coefficients}

This model assumes:

- Zero degree angle of attack.

- No conning motion.

- Nose first flight.

- Errors in estimating drag coefficients for supersonic, transonic, and subsonic speeds are $3 \%, 11 \%$, and $6 \%$, respectively.

\section{Results}

\section{Sabot Design}

A sabot was designed for each gun caliber. Each of these sabots, with the exception of the 5" gun sabot, is composed of three main elements:

- Pusher plate made of carbon steel (density $7.87 \mathrm{gram} / \mathrm{cm}^{3}$ )

○ 4-Segment sabot made of aluminum (density $2.7 \mathrm{gram} / \mathrm{cm}^{3}$ ). Each segment is reinforced with two- 0.25 " thick ribs shaped as circular segments.

- Nosecone made of fire retardant nylon (density $1.3 \mathrm{gram} / \mathrm{cm}^{3}$ ) that provides an interface to the fuse setter.

The 5" gun sabot entails the 4 sabot segments and the nosecone, but no pusher plate. The following table summarized the weights of individual elements and the total package weight reflecting weight savings after design refinements for each gun caliber. 
Table 2: Sabot Weights

\begin{tabular}{c|c|c|c|c}
\hline \hline \multirow{2}{*}{ Gun Caliber } & Sabot Weight & $\begin{array}{c}\text { Pusher Plate } \\
\text { Weight }\end{array}$ & $\begin{array}{c}\text { Nose Cone } \\
\text { Weight }\end{array}$ & Package Weight \\
\cline { 2 - 5 } & \multicolumn{4}{|c}{$[\mathrm{Kg}]$} \\
\hline 5" & 22.11 & 0.00 & 3.37 & 25.48 \\
8" & 40.77 & 3.14 & 3.37 & 47.27 \\
$10 "$ & 71.41 & 5.10 & 3.37 & 79.88 \\
$12 "$ & 93.73 & 7.70 & 3.37 & 104.79 \\
$14 "$ & 115.05 & 10.84 & 3.37 & 129.26 \\
$16 "$ & 133.92 & 14.52 & 3.37 & 151.81 \\
$18 ”$ & 149.91 & 18.74 & 3.37 & 172.02 \\
\hline \hline
\end{tabular}

\section{Interior ballistics}

Maximum $\mathrm{G}$ loading was constrained to $12.5 \mathrm{KGs}$ and travel at burnout was constrained to occur before muzzle exit. The model was run twice for each gun caliber, for breech pressures of 65 and $130 \mathrm{Ksi}$. The following tables summarize the main results of the different CONPRESS runs. Figures 8 through 10 depict the major parameters computed from the interior ballistics model.

Table 3: Interior Ballistic Characteristics of 64-Caliber Guns

\begin{tabular}{|c|c|c|c|c|c|c|c|c|c|}
\hline \multirow{2}{*}{\multicolumn{2}{|c|}{ Gun Caliber }} & \multirow{2}{*}{\multicolumn{2}{|c|}{$\begin{array}{c}\begin{array}{c}\text { Muzzle Exit } \\
\text { Velocity }\end{array} \\
{[\mathrm{m} / \mathrm{sec}]}\end{array}$}} & \multirow{2}{*}{\multicolumn{2}{|c|}{$\begin{array}{c}\text { Kinetic Energy } \\
{[\mathrm{MJ}]}\end{array}$}} & \multirow{2}{*}{\multicolumn{2}{|c|}{$\begin{array}{c}\text { G Loading } \\
{[\mathrm{Gs}]}\end{array}$}} & \multirow{2}{*}{\multicolumn{2}{|c|}{$\begin{array}{c}\text { Charge Mass } \\
{[\mathrm{kg}]}\end{array}$}} \\
\hline & & & & & & & & & \\
\hline [inch & {$[\mathrm{mm}]$} & $65 \mathrm{Ksi}$ & $130 \mathrm{Ksi}$ & $65 \mathrm{Ksi}$ & $130 \mathrm{Ksi}$ & $65 \mathrm{Ksi}$ & $130 \mathrm{Ksi}$ & $65 \mathrm{Ksi}$ & $130 \mathrm{Ksi}$ \\
\hline 5.0 & 127.0 & 999 & 1296 & 23 & 38 & 6399 & 11093 & 39 & 67 \\
\hline 6.1 & 155.0 & 1135 & 1450 & 29 & 48 & 6846 & 11634 & 67 & 111 \\
\hline 8.0 & 203.2 & 1364 & 1697 & 42 & 65 & 7748 & 12500 & 132 & 224 \\
\hline 10.0 & 254.0 & 1597 & 1918 & 57 & 83 & 8859 & 12500 & 222 & 441 \\
\hline 12.0 & 304.8 & 1792 & 2091 & 73 & 99 & 9735 & 12500 & 336 & 717 \\
\hline 14.0 & 355.6 & 1962 & 2237 & 87 & 113 & 10532 & 12500 & 468 & 1058 \\
\hline 16.0 & 406.4 & 2112 & 2362 & 101 & 127 & 11280 & 12500 & 616 & 1462 \\
\hline 18.0 & 457.2 & 2248 & 2473 & 115 & 139 & 12013 & 12500 & 780 & 1931 \\
\hline
\end{tabular}

Table 4: Interior Ballistic Characteristics of 64-Caliber Guns (continued)

\begin{tabular}{|c|c|c|c|c|c|c|c|c|c|}
\hline \multirow{2}{*}{\multicolumn{2}{|c|}{ Gun Caliber }} & \multirow{2}{*}{\multicolumn{2}{|c|}{$\begin{array}{c}\begin{array}{c}\text { Muzzle Exit } \\
\text { Pressure }\end{array} \\
{[\mathrm{MPa}]}\end{array}$}} & \multicolumn{4}{|c|}{ Travel at Burnout } & \multirow{2}{*}{\multicolumn{2}{|c|}{$\begin{array}{c}\text { Chamber Volume } \\
\text { [liter }]\end{array}$}} \\
\hline & & & & \multicolumn{2}{|c|}{$[\mathrm{cm}]$} & \multicolumn{2}{|c|}{ [caliber] } & & \\
\hline [inch & {$[\mathrm{mm}]$} & $65 \mathrm{Ksi}$ & $130 \mathrm{Ksi}$ & $65 \mathrm{Ksi}$ & $130 \mathrm{Ksi}$ & $65 \mathrm{Ksi}$ & $130 \mathrm{Ksi}$ & $65 \mathrm{Ksi}$ & $130 \mathrm{Ksi}$ \\
\hline 5.0 & 127.0 & 273 & 406 & 670 & 594 & 52.73 & 46.81 & 48 & 82 \\
\hline 6.1 & 155.0 & 240 & 341 & 777 & 675 & 50.11 & 43.56 & 81 & 136 \\
\hline 8.0 & 203.2 & 188 & 261 & 92 & 820 & 45.40 & 40.35 & 161 & 273 \\
\hline 10.0 & 254.0 & 142 & 216 & 1026 & 1088 & 40.83 & 42.84 & 271 & 538 \\
\hline 12.0 & 304.8 & 109 & 169 & 1103 & 1270 & 36.19 & 41.68 & 410 & 875 \\
\hline 14.0 & 355.6 & 85 & 131 & 1152 & 1410 & 32.40 & 39.66 & 570 & 1291 \\
\hline 16.0 & 406.4 & 67 & 103 & 1183 & 1521 & 29.13 & 37.41 & 752 & 1784 \\
\hline 18.0 & 457.2 & 53 & 81 & 1202 & 1611 & 26.29 & 35.24 & 951 & 2356 \\
\hline
\end{tabular}


Table 5: Interior Ballistic Characteristics of 200-Caliber Guns

\begin{tabular}{c|l|l|l|c|c|c|c|c|c}
\hline \hline \multirow{2}{*}{ Gun Caliber } & \multicolumn{2}{c|}{$\begin{array}{c}\text { Muzzle Exit } \\
\text { Velocity }\end{array}$} & \multicolumn{2}{c|}{ Kinetic Energy } & \multicolumn{2}{c}{ G Loading } & \multicolumn{2}{c}{ Charge Mass } \\
\cline { 3 - 10 } & \multicolumn{2}{|c|}{$[\mathrm{m} / \mathrm{sec}]$} & \multicolumn{2}{c|}{$[\mathrm{MJ}]$} & \multicolumn{2}{c}{$[\mathrm{Gs}]$} & \multicolumn{2}{c}{$[\mathrm{kg}]$} \\
\hline$[$ inch & {$[\mathrm{mm}]$} & $65 \mathrm{Ksi}$ & $130 \mathrm{Ksi}$ & $65 \mathrm{Ksi}$ & $130 \mathrm{Ksi}$ & $65 \mathrm{Ksi}$ & $130 \mathrm{Ksi}$ & $65 \mathrm{Ksi}$ & $130 \mathrm{Ksi}$ \\
\hline 5.0 & 127.0 & 1506 & 1846 & 51 & 77 & 4946 & 8061 & 92 & 146 \\
8.0 & 203.2 & 1920 & 2262 & 84 & 116 & 5567 & 8820 & 282 & 422 \\
10.0 & 254.0 & 2161 & 2494 & 105 & 141 & 6163 & 9694 & 451 & 655 \\
12.0 & 304.8 & 2353 & 2674 & 126 & 162 & 6655 & 10426 & 653 & 930 \\
\hline \hline
\end{tabular}

Table 6: Interior Ballistic Characteristics of 200-Caliber Guns (continued)

\begin{tabular}{c|c|c|c|c|c|c|c|c|c}
\hline \hline \multirow{2}{*}{ Gun Caliber } & $\begin{array}{c}\text { Muzzle Exit } \\
\text { Pressure }\end{array}$ & \multicolumn{4}{c|}{ Travel at Burnout } & \multicolumn{2}{c}{ Chamber Volume } \\
\cline { 3 - 10 } & & \multicolumn{2}{|c|}{$[\mathrm{MPa}]$} & \multicolumn{2}{|c}{$[\mathrm{cm}]$} & \multicolumn{2}{c}{$[$ caliber] } & \multicolumn{2}{c}{$[$ liter] } \\
\hline$[$ inch & {$[\mathrm{mm}]$} & $65 \mathrm{Ksi}$ & $130 \mathrm{Ksi}$ & $65 \mathrm{Ksi}$ & $130 \mathrm{Ksi}$ & $65 \mathrm{Ksi}$ & $130 \mathrm{Ksi}$ & $65 \mathrm{Ksi}$ & $130 \mathrm{Ksi}$ \\
\hline 5.0 & 127.0 & 160 & 202 & 1684 & 1386 & 132.63 & 109.15 & 113 & 178 \\
8.0 & 203.2 & 91 & 104 & 2116 & 1648 & 104.14 & 81.09 & 344 & 514 \\
10.0 & 254.0 & 62 & 68 & 2231 & 1680 & 87.85 & 66.15 & 550 & 799 \\
12.0 & 304.8 & 44 & 47 & 2291 & 1686 & 75.17 & 55.33 & 797 & 1136 \\
\hline \hline
\end{tabular}

\section{Exterior Ballistics}

The following tables summarize the main results of the different runs of the exterior ballistics model. Figures 11 through 16 illustrate these results versus the gun caliber for the two barrel lengths and breech pressures:

Table 7: Exterior Ballistic Performance of 64-Caliber Guns

\begin{tabular}{c|c|c|c|c|c|c|c}
\hline \hline \multirow{2}{*}{ Gun Caliber } & \multicolumn{2}{c|}{ Max Range } & \multicolumn{2}{c|}{ Firing Angle } & \multicolumn{2}{c}{ Range Increase } \\
\cline { 3 - 6 } & \multicolumn{2}{c}{ [mile] } & \multicolumn{2}{c}{ [degree] } & \multirow{2}{*}{ [mile] } & $\%$ \\
\hline [inch] & {$[\mathrm{mm}]$} & $65 \mathrm{Ksi}$ & $130 \mathrm{Ksi}$ & $65 \mathrm{Ksi}$ & $130 \mathrm{Ksi}$ & & \\
\hline 5.0 & 127.0 & 32 & 67 & 52 & 51 & 35 & 108.23 \\
6.1 & 155.0 & 46 & 91 & 52 & 50 & 45 & 98.04 \\
8.0 & 203.2 & 77 & 137 & 51 & 49 & 60 & 77.16 \\
10.0 & 254.0 & 118 & 185 & 49 & 48 & 67 & 57.07 \\
12.0 & 304.8 & 157 & 227 & 49 & 48 & 70 & 44.30 \\
14.0 & 355.6 & 195 & 265 & 48 & 47 & 69 & 35.52 \\
16.0 & 406.4 & 232 & 300 & 48 & 47 & 68 & 29.09 \\
18.0 & 457.2 & 268 & 332 & 47 & 47 & 64 & 23.97 \\
\hline \hline
\end{tabular}


Table 8: Exterior Ballistic Performance of 200-Caliber Guns

\begin{tabular}{c|c|c|c|c|c|c|c}
\hline \hline \multirow{2}{*}{ Gun Caliber } & \multicolumn{2}{|c|}{ Max Range } & \multicolumn{2}{c|}{ Firing Angle } & \multicolumn{2}{c}{ Range Increase } \\
\cline { 3 - 7 } & \multicolumn{2}{|c|}{ [mile] } & \multicolumn{2}{c}{ [degree] } & \multicolumn{2}{c}{} \\
\hline [inch] & {$[\mathrm{mm}]$} & $65 \mathrm{Ksi}$ & $130 \mathrm{Ksi}$ & $65 \mathrm{Ksi}$ & $130 \mathrm{Ksi}$ & {$[\mathrm{mile}]$} & $\%$ \\
\hline 5.0 & 127.0 & 101 & 169 & 50 & 48 & 68 & 67.09 \\
8.0 & 203.2 & 185 & 271 & 48 & 47 & 86 & 46.43 \\
10.0 & 254.0 & 245 & 338 & 48 & 47 & 93 & 38.20 \\
12.0 & 304.8 & 297 & 395 & 47 & 47 & 97 & 32.80 \\
\hline \hline
\end{tabular}

\section{Conclusions}

The 200-caliber gun barrels offer definite advantages over the 64-caliber barrels in terms of its: (1) longer range potential; (2) efficient propellant usage and economy for the smaller bore diameters; (3) lower projectile G loads, and (4) lower muzzle exit pressures. This analysis focused only on the range potential of a ballistic round fired from different gun calibers with different barrel lengths and breech pressures. Cancellation of Raytheon's rocket-assisted EX171 Extended Range Guided Munition (ERGM) program, the vague destiny of Zona's (Zona Technology Inc.) Arizona Glider (AG) gliding projectile, and the very expensive cost of the cruise missile left us with no other options to analyze for meeting the USMC STOM/OPFTS requirements.

\section{References}

[1] Milligan, M., "U.S. Marine Corps Naval Surface Fire Support Requirements," Marine Corps Combat Development Command (MCCDC), 7th International Artillery and Indirect Fire Symposium \& Exhibition, 17-19 June 2002, http://www.dtic.mil/ndia/2002artillery/milligan.pdf

[2] Hause, 7th International Artillery and Indirect Fire Symposium \& Exhibition, 17-19 June 2002, http://www.dtic.mil/ndia/2002artillery/hause.pdf

[3] Oberle, W. F., "Constant Breech Pressure Interior Ballistics Code CONPRESS: Theory and User's Manual," Technical Report ARL-TR-199, US Army Research Laboratory, Aberdeen Proving Ground, MD, 1993, http://www.dtic.mil/cgibin/GetTRDoc?AD=ADA275491\&Location=U2\&doc=GetTRDoc.pdf.

[4] Norton, S. A., "CONPRESS in Mathcad: Implementation of the CONPRESS Constant Pressure Interior Ballistics Code as a Mathcad Live Scratchpad Document," Defense Technology, Incorporated, Arlington, VA, 1996.

[5] MacCoy, R. L., "MC Drag - A Computer Program for Estimating the Drag Coefficients of Projectiles," Technical Report ARBRL-TR-02293, US Army Armament Research and Development Command, Ballistics Research Laboratory, Aberdeen Proving Ground, MD, 1981, http://www.ada.ru/guns/ballistic/bc/McCoy.pdf

[6] National Geophysical Data Center, National Oceanic and Atmospheric Administration, Boulder, CO, 1976.

[7] Wilson, G. et al, "AOT Gun," Applied Ordnance Technology, 39th NDIA Guns \& Ammunition Conference Baltimore, MD April 2004, www.dtic.mil/ndia/2004guns/fri/aot.ppt

[8] Adams, M. et al, "Advanced Modular Gun: Developing Tomorrow's Weapon Systems with Today's Technology," Applied Ordnance Technology and NSWC Dahlgren, 41st NDIA Gun and Missile Systems Conference Sacramento, CA March 2006, http://www.dtic.mil/ndia/2006garm/tuesday/coladonato.pdf 


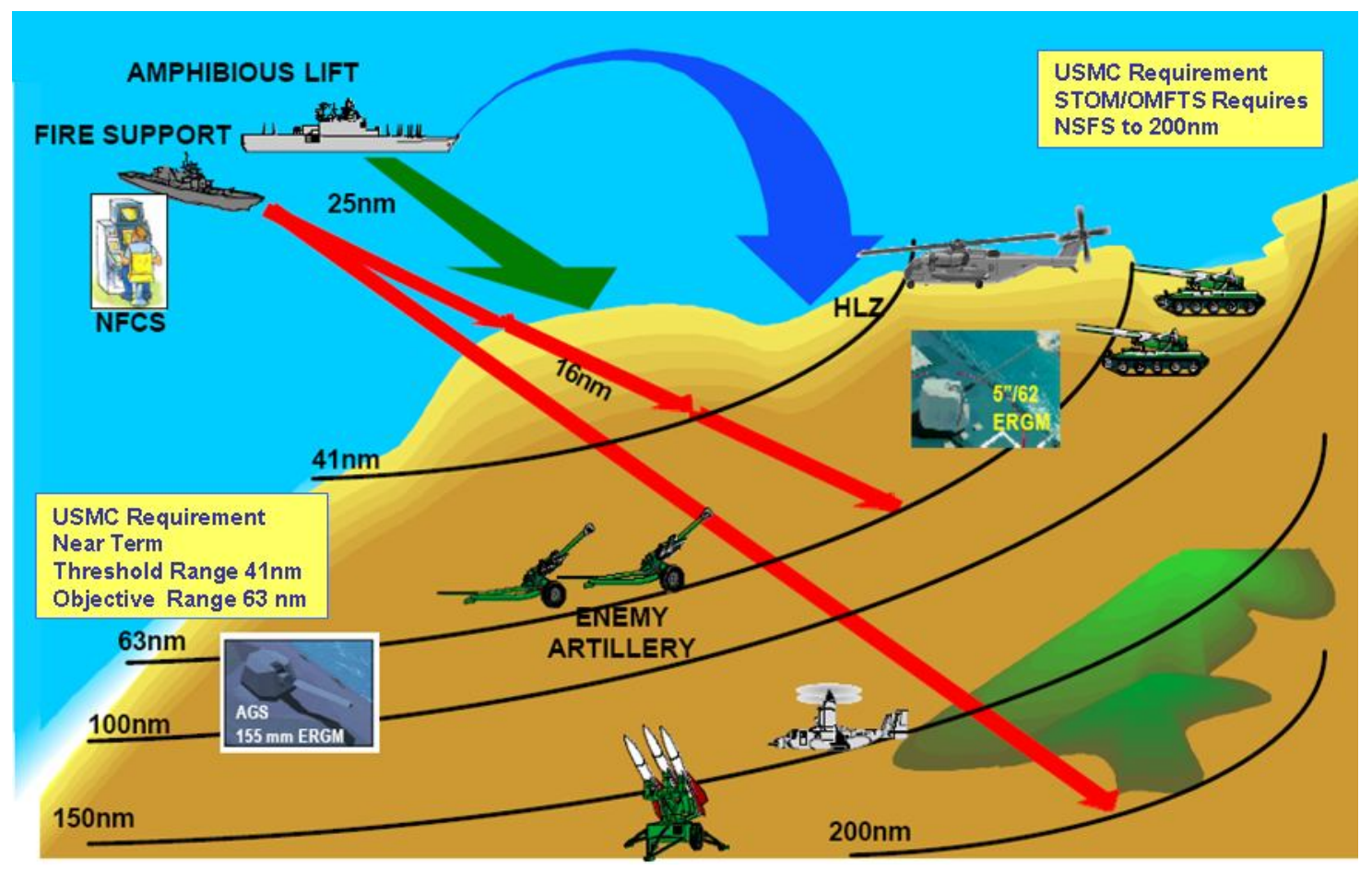

Figure 1: The USMC Requirements for Naval Surface Fire Support

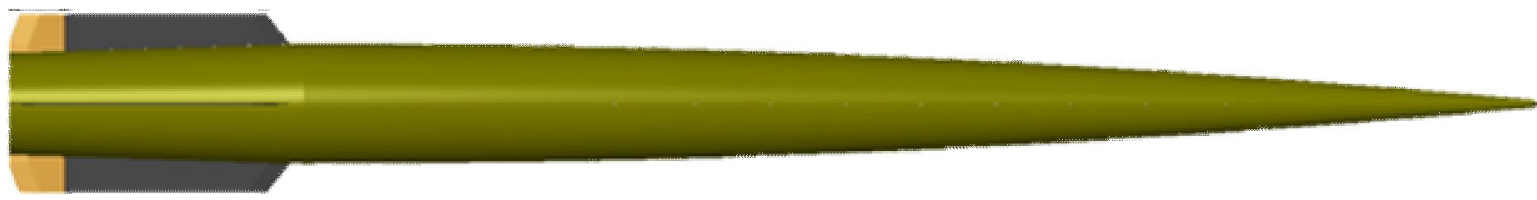

Figure 2: The 5"/12 Calibers, 100 lbs, Dart-Like Barrage Round

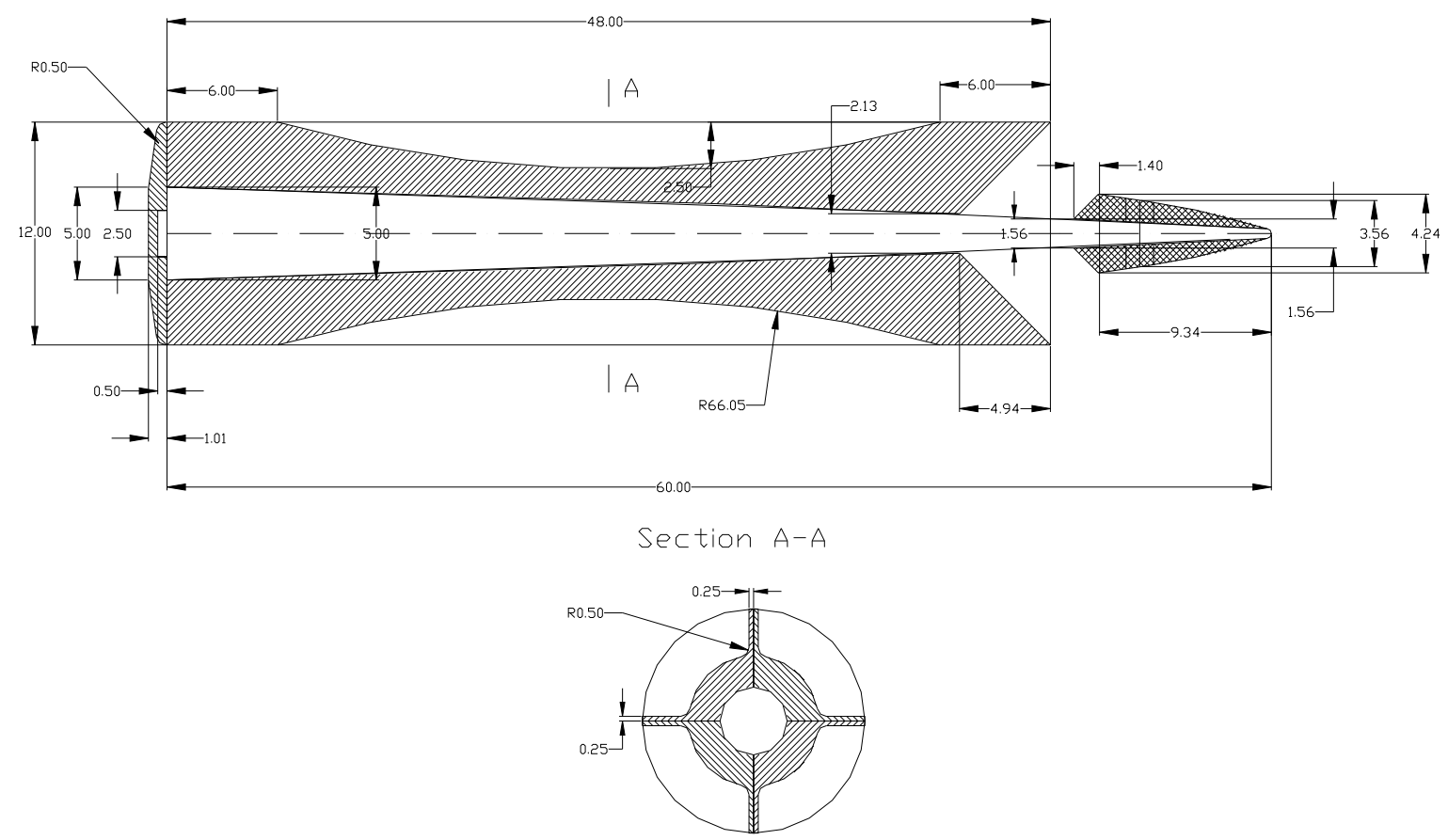

Figure 3: Design Drawing for the 12" Caliber Sabot 


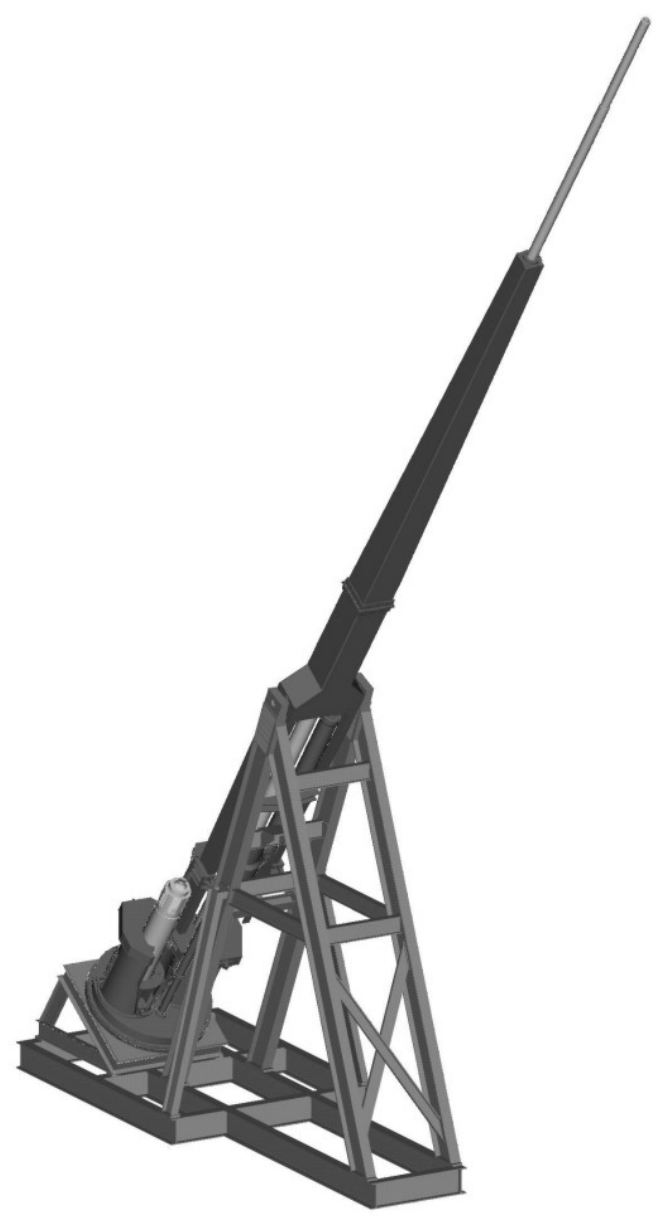

Figure 4: The Applied Ordnance Technology AOT or XLR Gun ${ }^{7,8}$; AOT Claims It Is Capable of Developing 200 Caliber Barrels

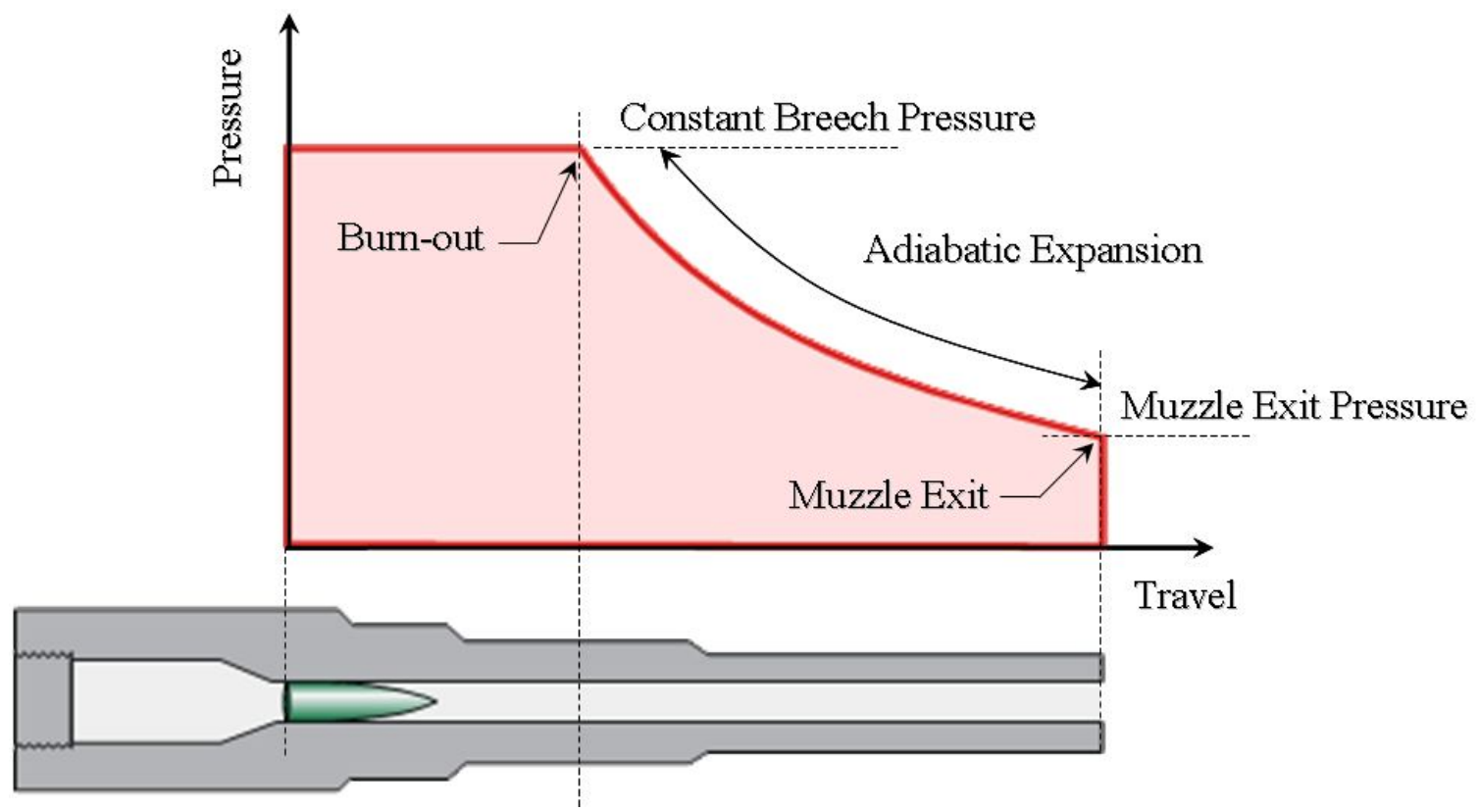

Figure 5: Schematic of the CONPRESS Model and the Pressure versus Travel Chart 


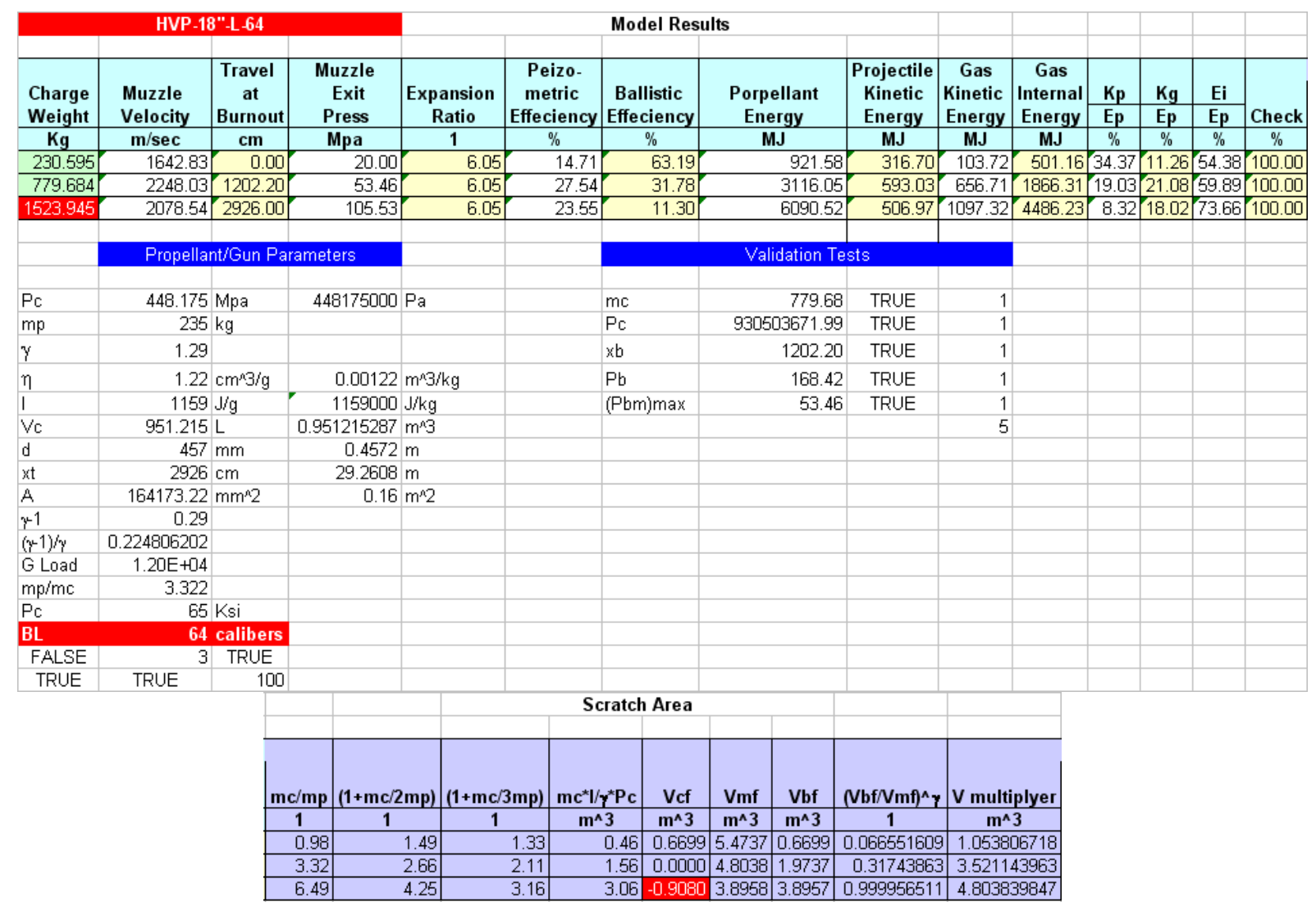

Figure 6: The Microsoft Excel Implementation of the FORTRAN Based CONPRESS Model 


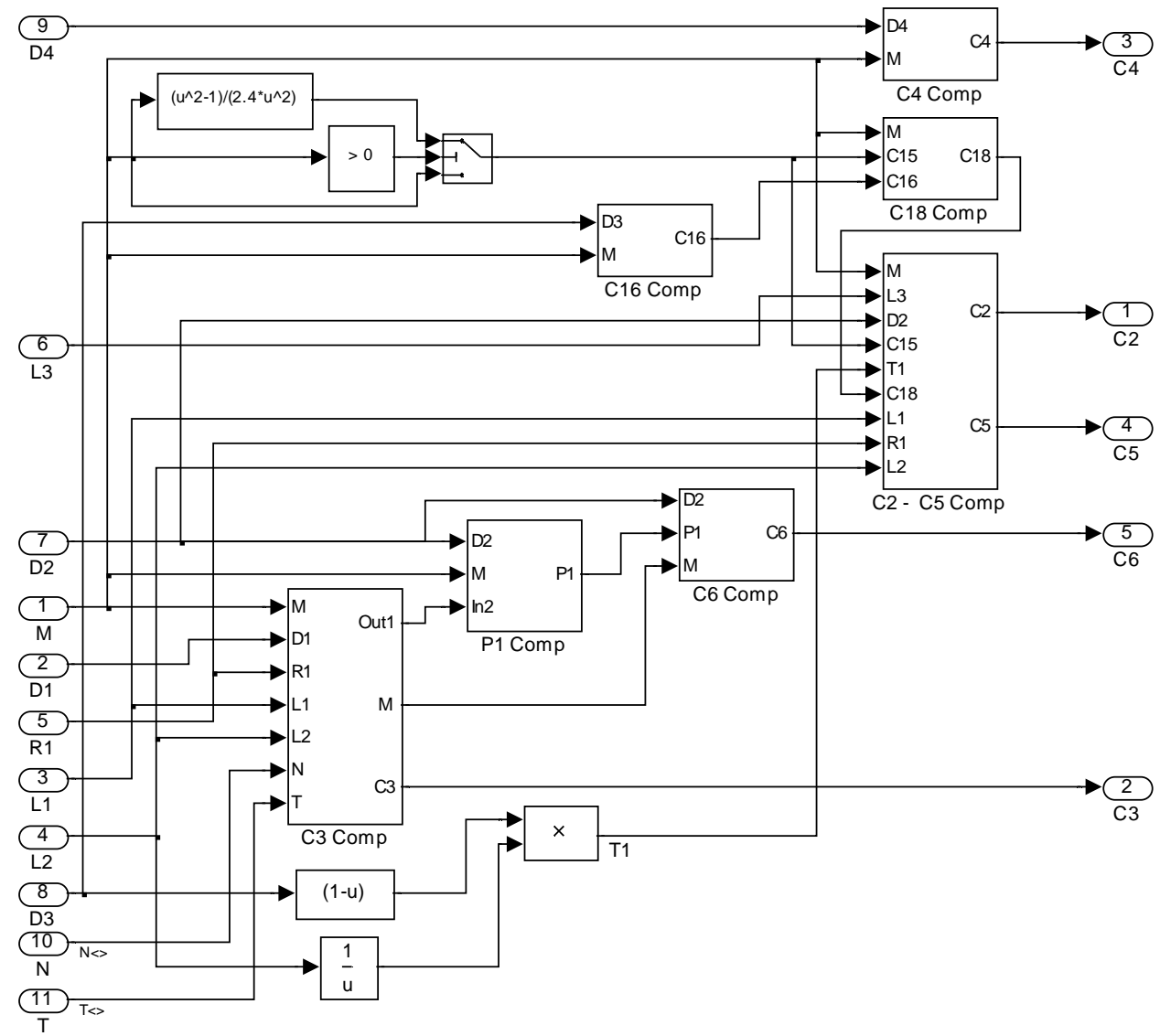

Figure 7: The McDrag Model Core

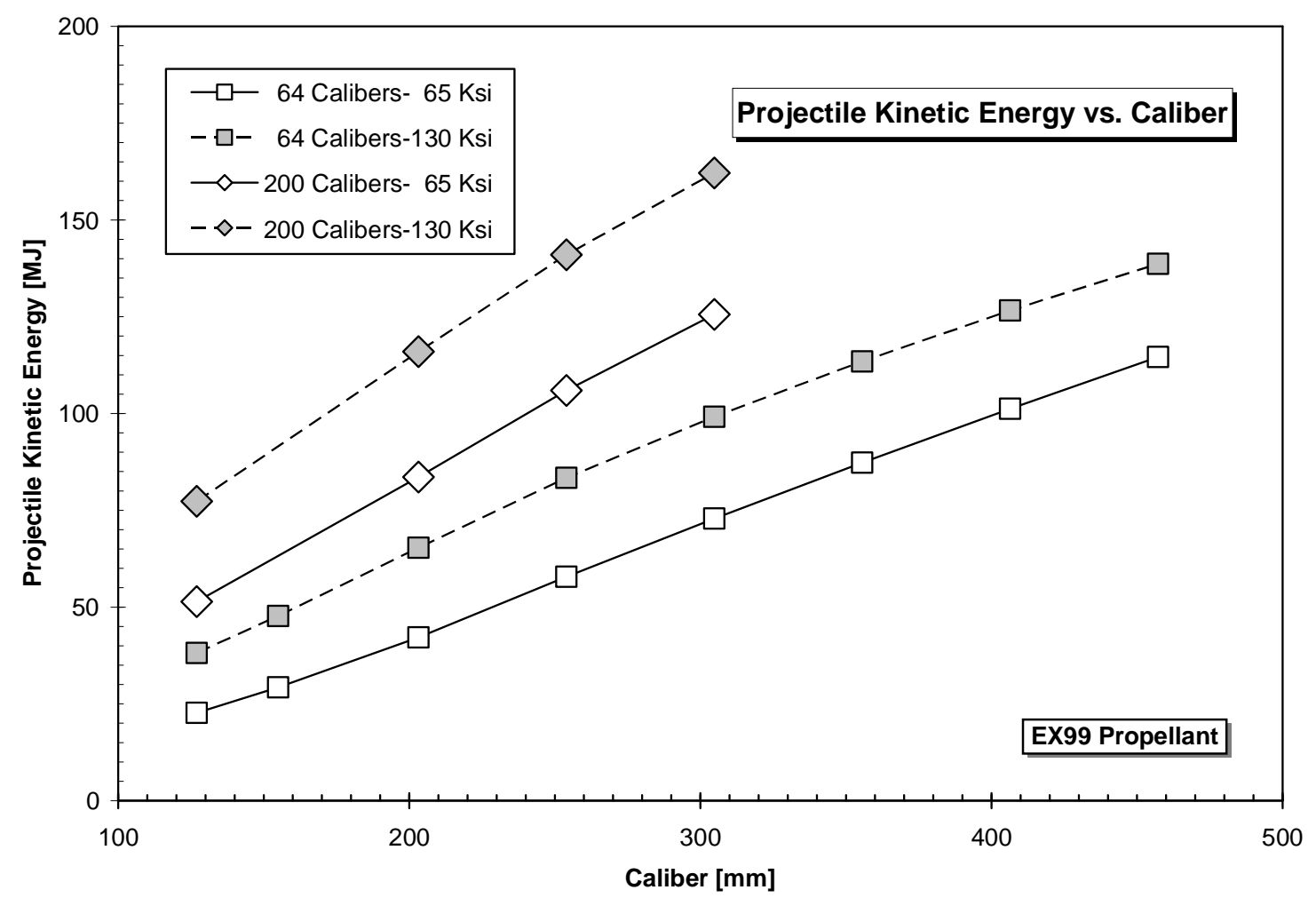

Figure 8: Projectile Kinetic Energy versus Gun Caliber for the Two Barrel Lengths and Breech Pressures 


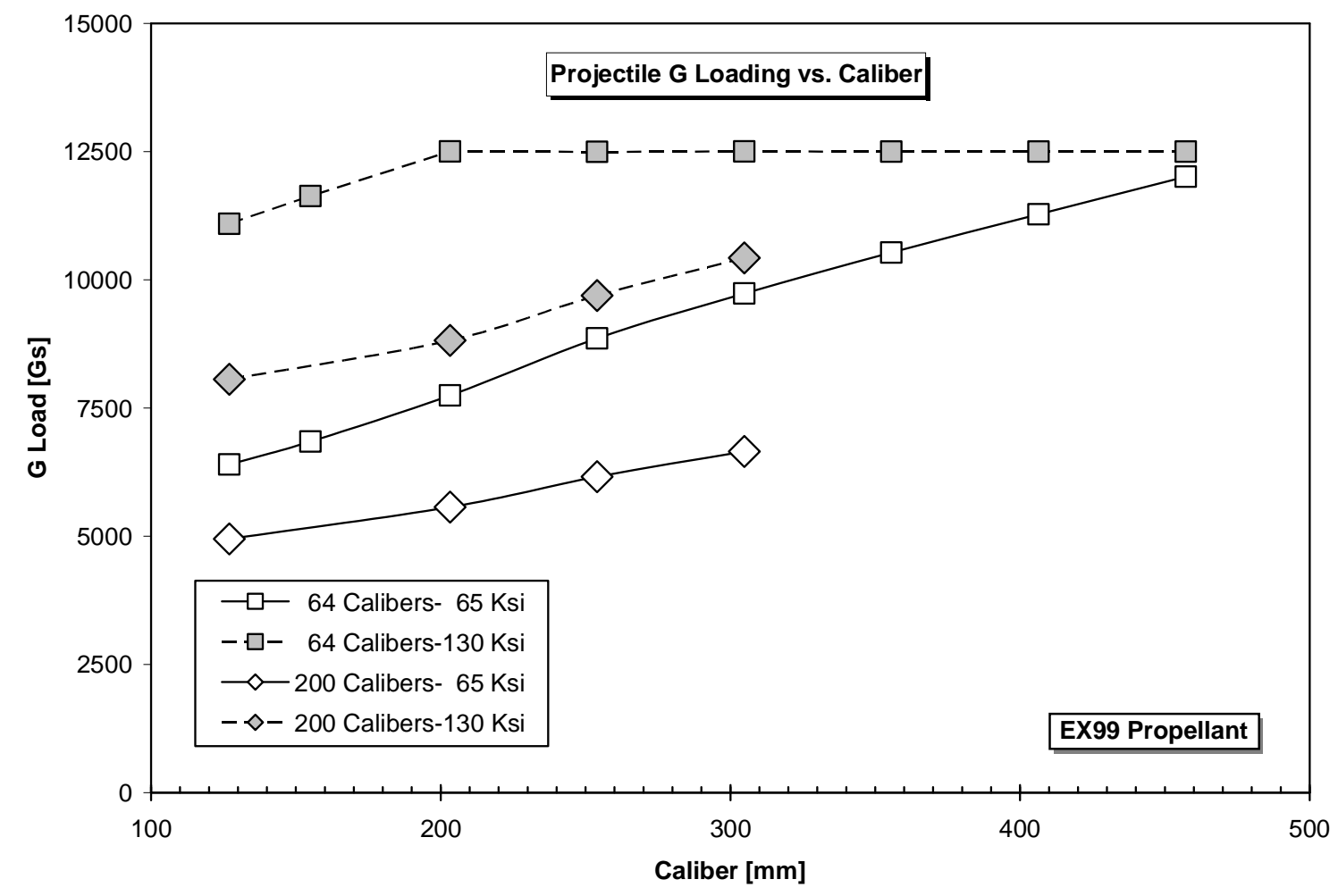

Figure 9: Projectile G Loading versus Gun Caliber for the Two Barrel Lengths and Breech Pressures

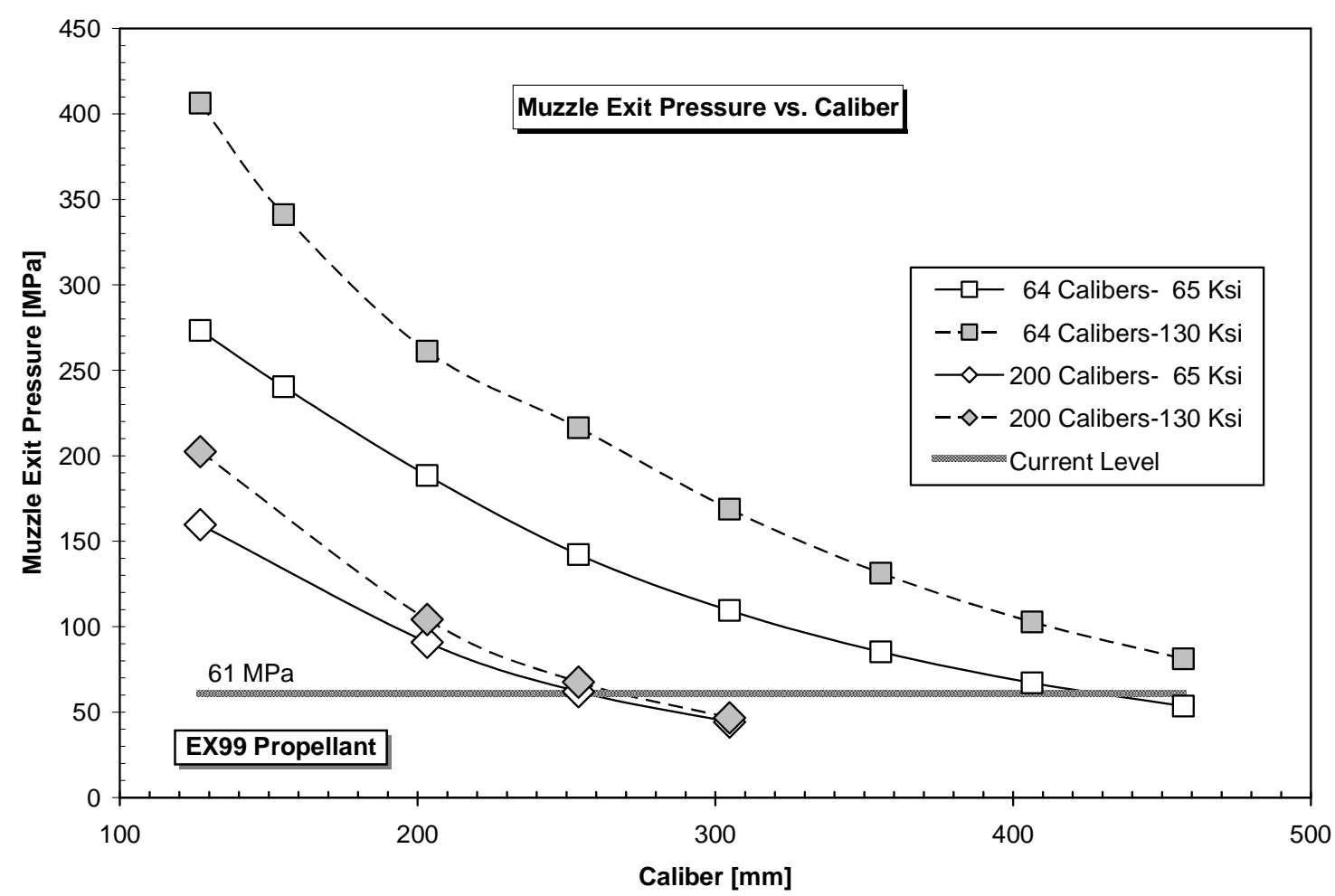

Figure 10: Muzzle Exit Pressure versus Gun Caliber for the Two Barrel Lengths and Breech Pressures 


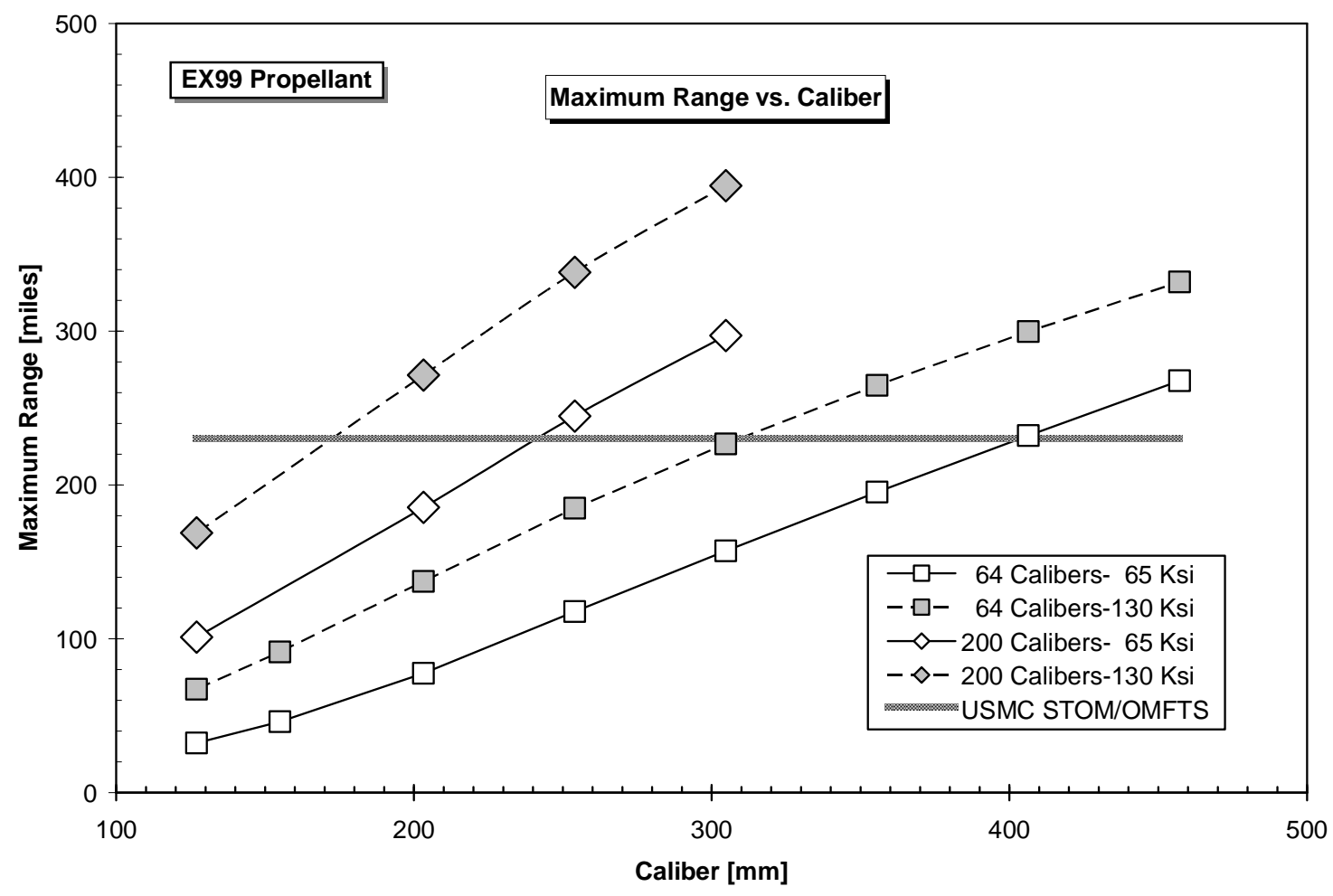

Figure 11: Maximum Range versus Gun Caliber for the Two Barrel Lengths and Breech Pressures

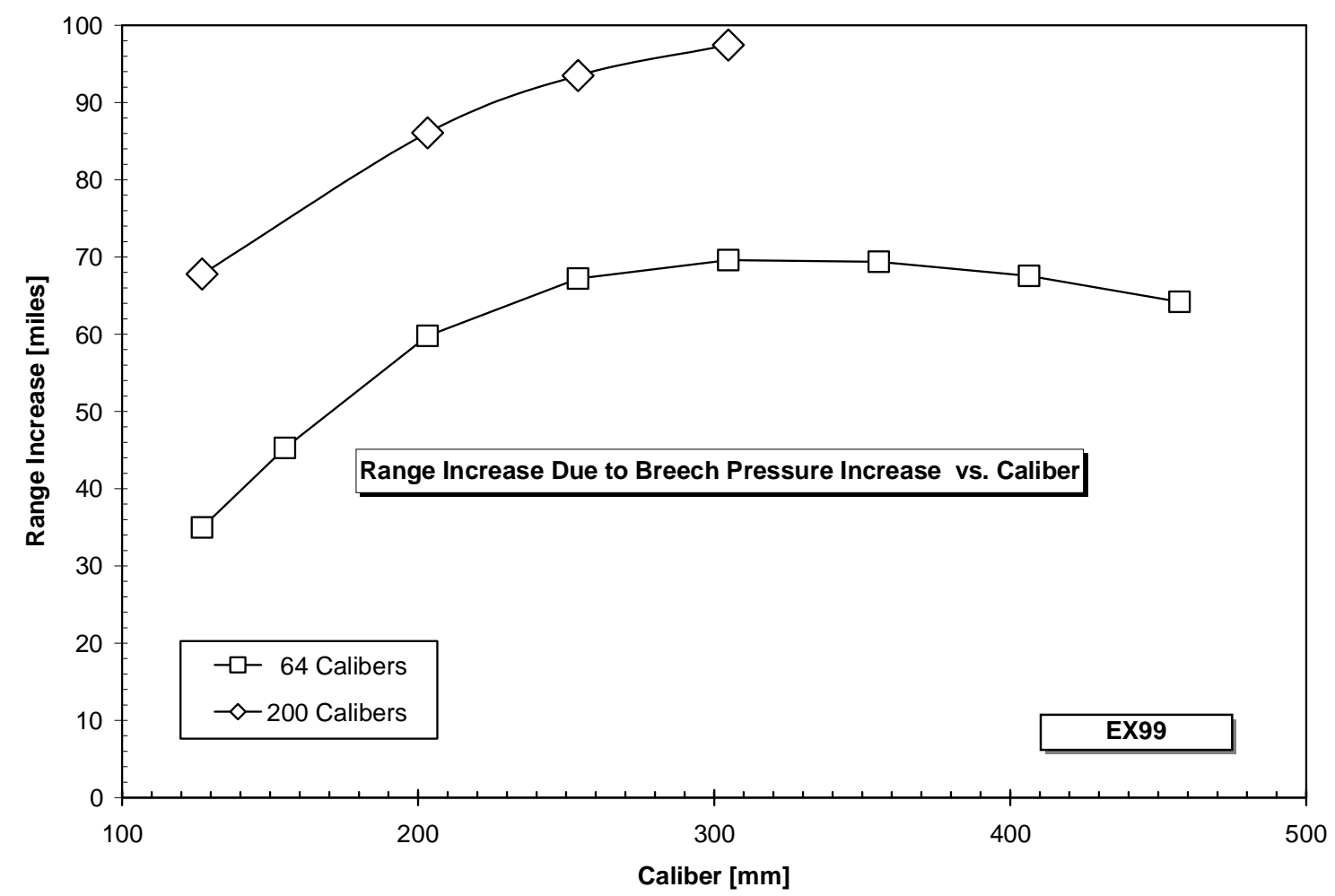

Figure 12: Range Increase Due to Breech Pressure Increase versus Gun Caliber for the Two Barrel Lengths 


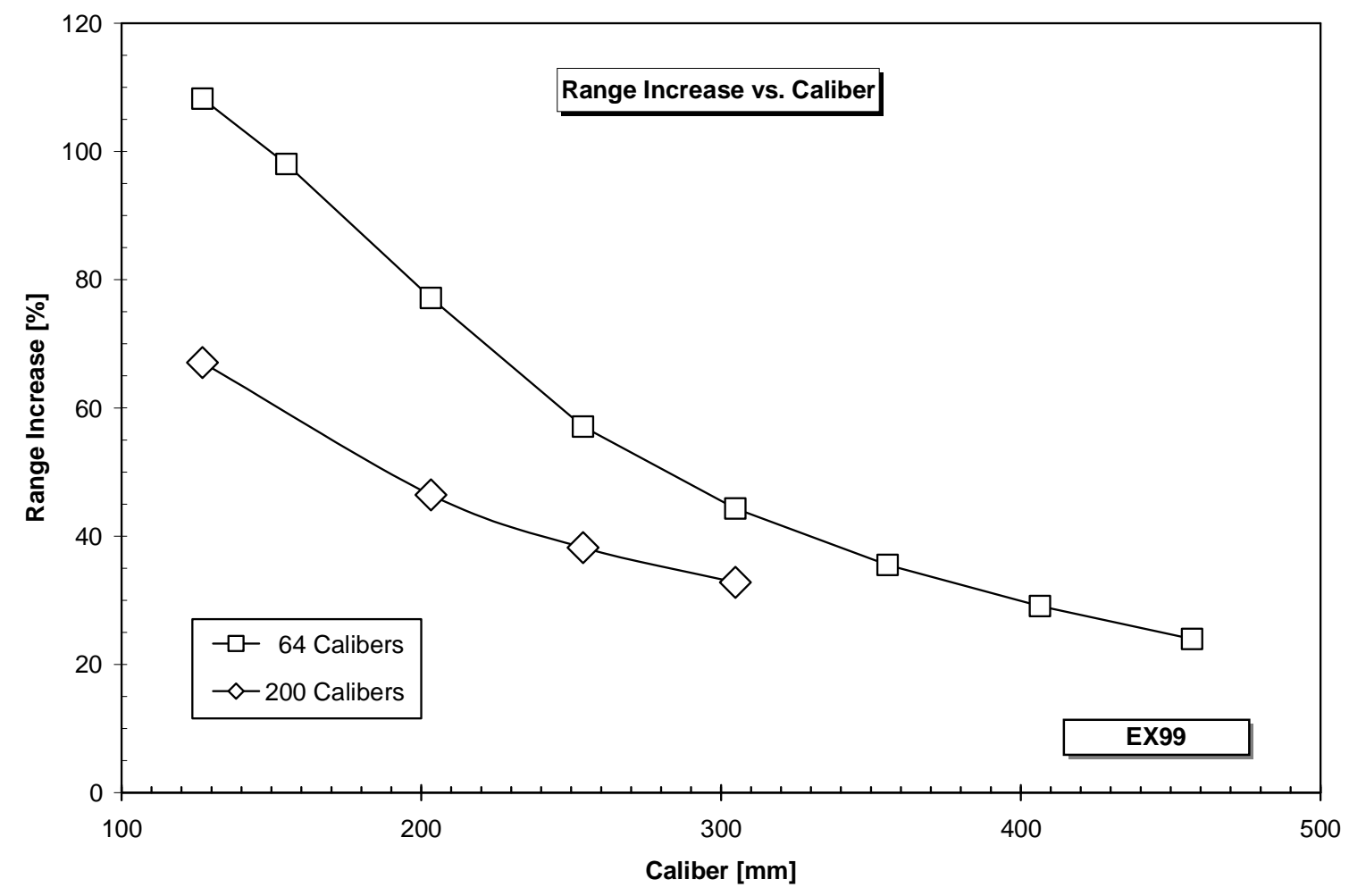

Figure 13: Percentage Range Increase Due to Increase in Breech Pressure versus Gun Caliber for the Two Barrel Lengths

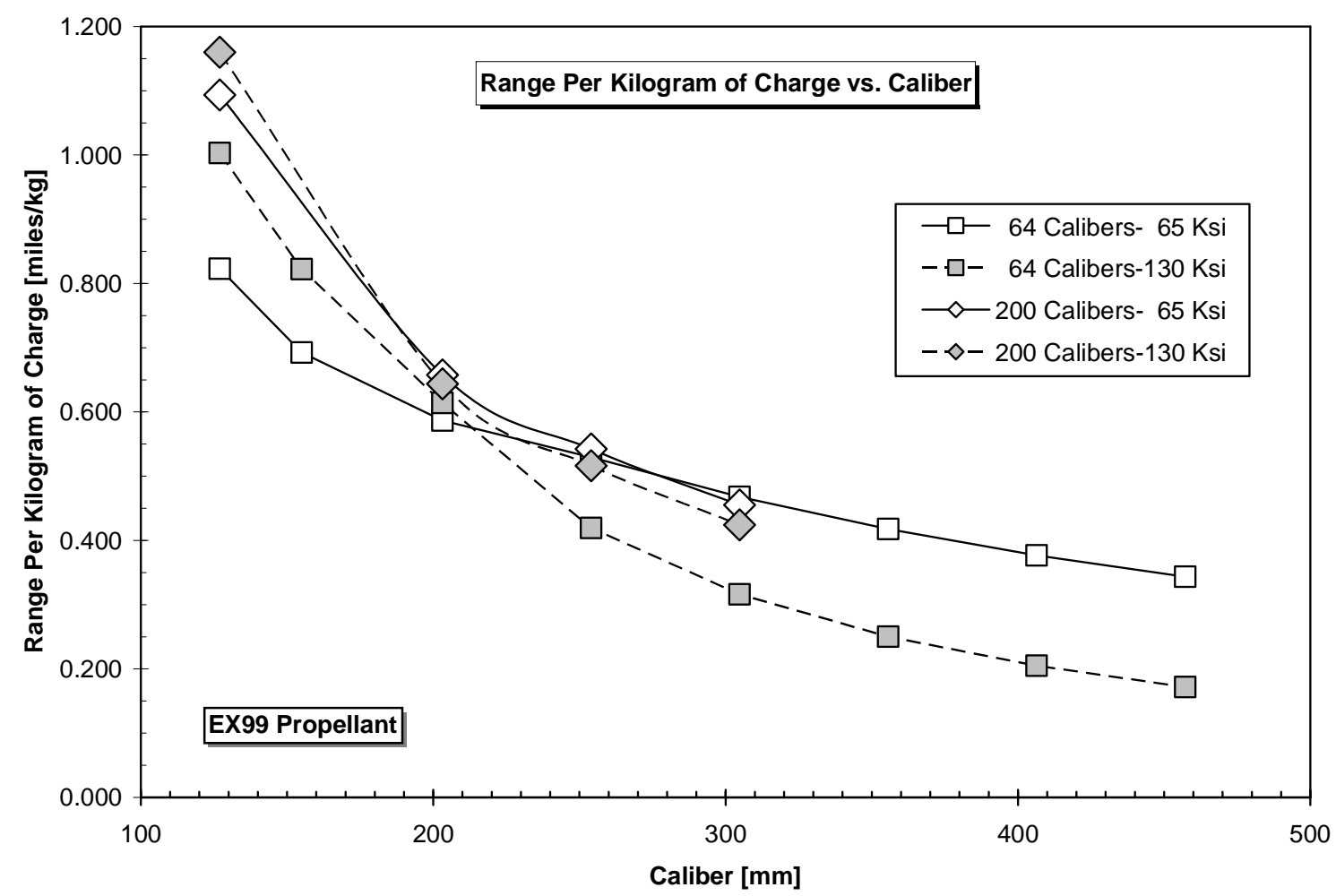

Figure 14: Range per Kilogram of Charge versus Gun Caliber for the Two Barrel Lengths and Breech Pressures 


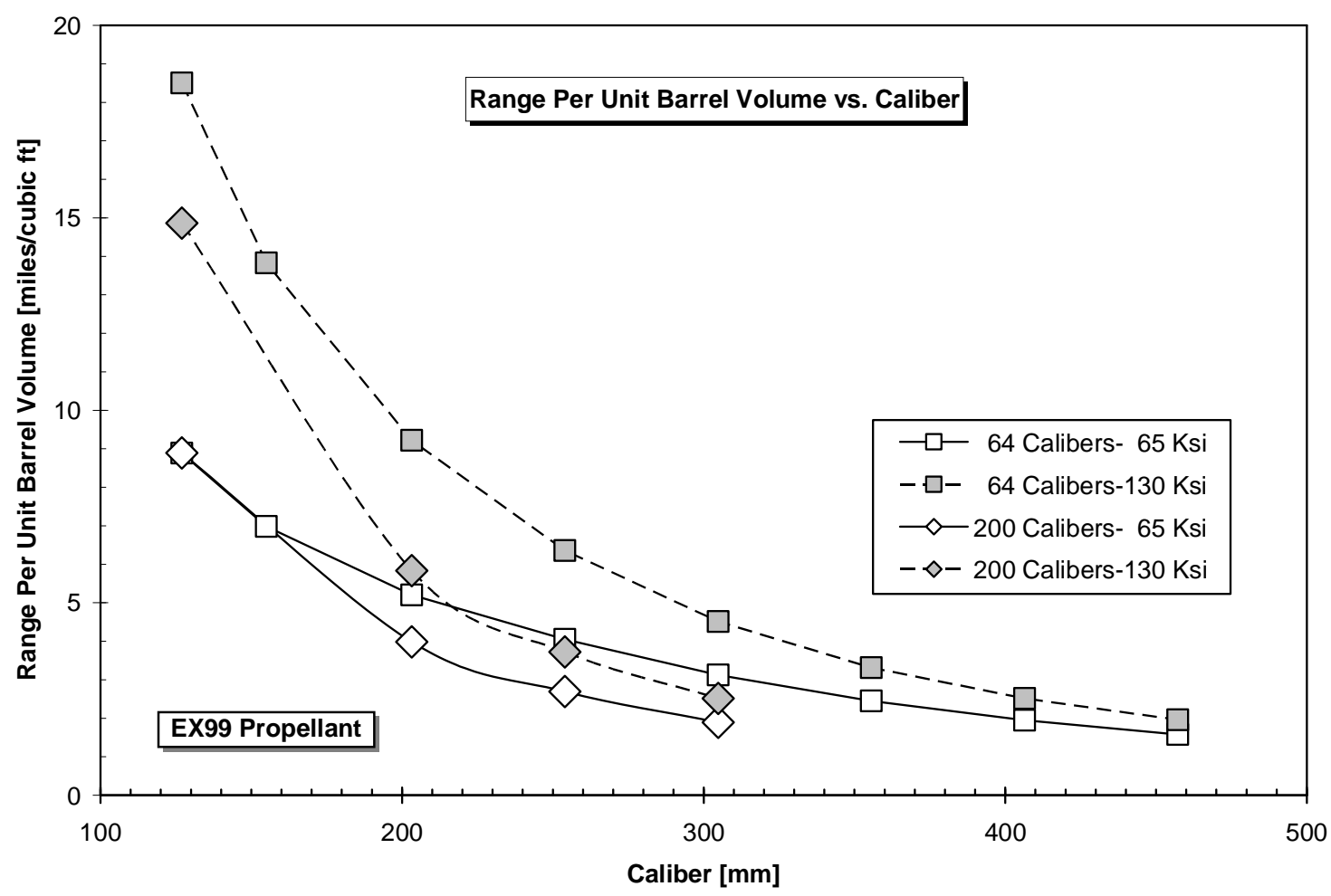

Figure 15: Range per Unit Barrel Volume versus Gun Caliber for the Two Barrel Lengths and Breech Pressures

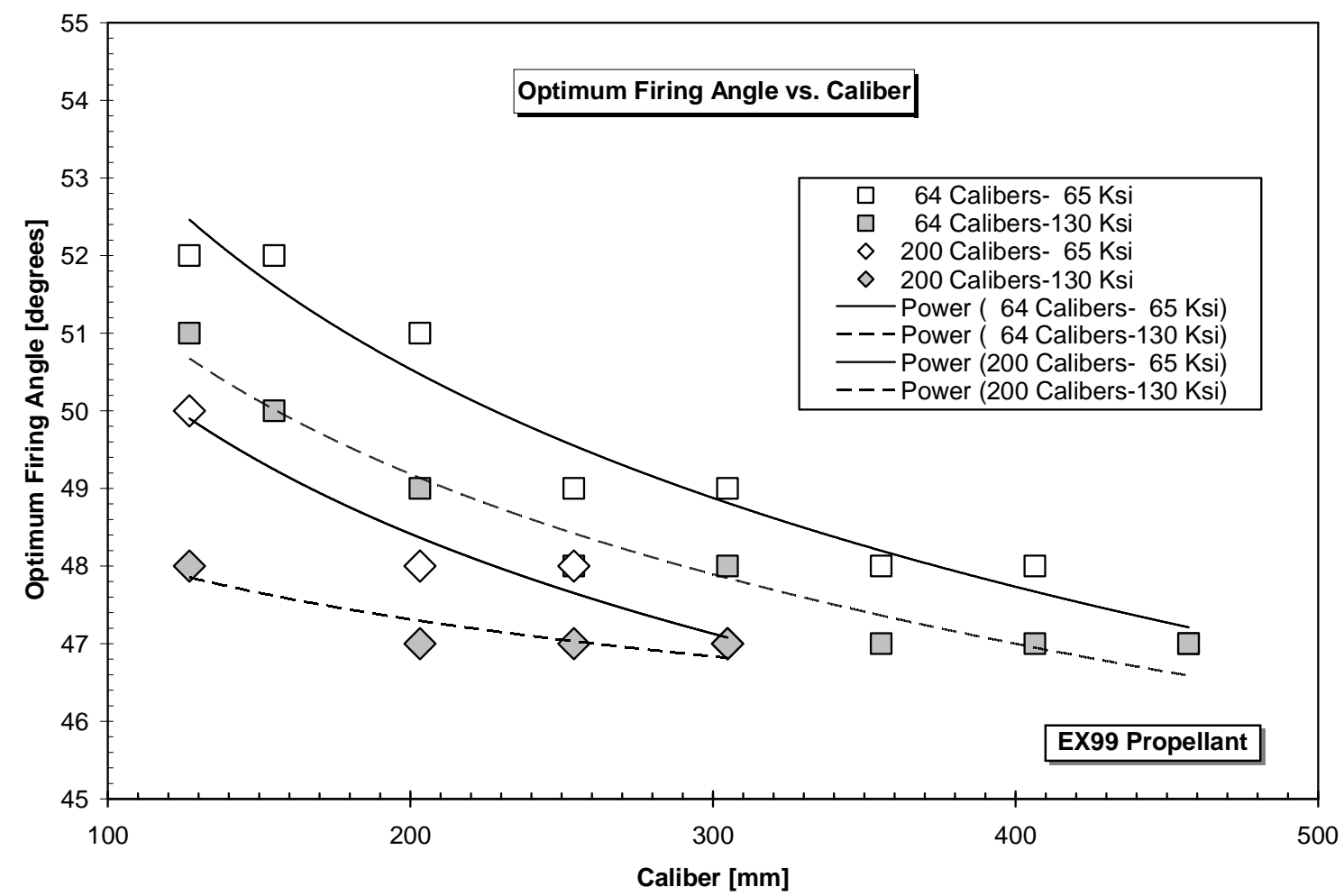

Figure 16: Optimum Firing Angle Curves versus Gun Caliber for the Two Barrel Lengths and Breech Pressures 